\title{
PENERAPAN MODEL PEMBELAJARAN TEAM ASSISTED INDIVIDUALIZATION (TAI) DILENGKAPI CATATAN TERBIMBING (GUIDED NOTE) UNTUK MENINGKATKAN AKTIVITAS DAN PRESTASI BELAJAR SISWA PADAMATERI POKOK KELARUTAN DAN HASIL KALI KELARUTAN KELAS XI MIA 2 SMA NEGERI 2 SUKOHARJO TAHUN PELAJARAN 2015/2016
}

\author{
Rosiana Melia Sari, Sri Yamtinah ${ }^{*}$, dan Widiastuti Agustina E.S. \\ Program Studi Pendidikan Kimia, FKIP, Universitas Sebelas Maret, Surakarta, Indonesia \\ *Keperluan Korespondensi, HP: 081227182520, e-mail:jengtina_sp@yahoo.com
}

\begin{abstract}
ABSTRAK
Penelitian ini bertujuan untuk meningkatkan aktivitas dan prestasi belajar siswa pada materi kelarutan dan hasil kali kelarutan kelas XI MIA 2 SMA Negeri 2 Sukoharjo menggunakan model pembelajaranan Team Assisted Individualization (TAl) dilengkapi catatan terbimbing (guided note). Penelitian ini merupakan Penelitian Tindakan Kelas yang dilaksanakan dalam dua siklus, setiap siklus terdiri dari perencanaan, pelaksanaan, observasi, dan refleksi. Subjek penelitian adalah siswa kelas XI MIA 2 SMA Negeri 2 Sukoharjo Tahun Pelajaran 2015/2016. Sumber data adalah guru dan siswa. Teknik pengumpulan data adalah berupa tes dan observasi, wawancara, angket dan kajian dokumen. Analisis data menggunakan teknik analisis deskriptif kualitatif. Hasil penelitian pada prasiklus untuk aktivitas belajar kategori tinggi sebesar $30,76 \%$. Capaian pada siklus I untuk aspek aktivitas belajar, pengetahuan, sikap dan keterampilan masing - masing sebesar 56,41\%, 61,53\%, 94,87\% dan 100\%. Capaian pada siklus II aspek aktivitas belajar dan pengetahuan masing - masing sebesar 79,49\%. Berdasarkan hasil penelitian dapat disimpulkan bahwa penerapan model pembelajaran Team Assisted Individualization (TAI) dilengkapi catatan terbimbing (guided note) dapat meningkatkan aktivitas dan prestasi belajar siswa pada materi pokok kelarutan dan hasil kelarutan kelas XI MIA 2 SMA Negeri 2 Sukoharjo.
\end{abstract}

Kata Kunci: team assisted individualization (TAI), catatan terbimbing (guided note), aktivitas belajar, prestasi belajar, kelarutan dan hasil kali kelarutan

\section{PENDAHULUAN}

Kimia merupakan mata pelajaran
dalam pembelajaran kimia yang
mempelajari tentang komposisi, sifat,
struktur, perubahan materi serta energi
yang menyertai perubahan tersebut [1].
Kimia berkaitan dengan dua hal yaitu
kimia sebagai produk dan proses. Kimia
sebagai produk meliputi sekumpulan
pengetahuan yang terdiri atas fakta-
fakta, konsep - konsep dan prinsip -
prinsip kimia. Kimia sebagai proses
meliputi keterampilan dan sikap ilmiah.
Dengan demikian, pembelajaran kimia
harus memperhatikan karakteristik ilmu
kimia sebagai produk dan proses [2].

Pembelajaran kimia pada hakikatnya merupakan pembelajaran yang memungkinkan peserta didik aktif mencari dan menemukan konsep serta prinsip yang dipelajari secara holistik dan bermakna. Hal ini sesuai dengan proses pembelajaran pada Kurikulum 2013 yakni menuntut adanya partisipasi aktif dari seluruh siswa. Dalam hal ini, siswa merupakan subjek belajar (student centered) dan proses pembelajarannya menggunakan pendekatan yang bersifat ilmiah (scientific approach) berdasarkan kompetensi tertentu, bukan transfer pengetahuan (transfer of knowledge). Agar Kurikulum 2013 dapat berjalan dengan baik, guru diharapkan dapat 
mengarahkan siswa untuk lebih terlibat aktif dalam mengembangkan potensi di dalam dirinya dan meningkatkan kemampuan dalam memecahkan masalah agar diperoleh prestasi belajar yang maksimal [3].

Sekolah Menengah Atas (SMA) Negeri 2 Sukoharjo merupakan salah satu sekolah yang menerapkan Kurikulum 2013. Namun, berdasarkan hasil observasi selama Program Pengalaman Lapangan (PPL) tanggal 3, 7 dan 9 september 2015 dan wawancara dengan guru kimia tanggal 4 januari 2016, terdapat permasalahan mengenai implementasi Kurikulum 2013 dalam proses pembelajaran kimia di SMA Negeri 2 Sukoharjo yakni pembelajaran kimia di kelas masih berpusat pada guru (teacher centered learning), guru hanya mentransfer pengetahuan kepada siswa secara satu arah. Proses pembelajarannya menggunakan metode konvensional yaitu ceramah dalam penyampaian materi pelajaran serta media pembelajaran yang kurang inovatif dan kurang melibatkan aktivitas siswa.

Hasil wawancara juga diketahui bahwa materi kelarutan dan hasil kali kelarutan merupakan salah satu materi kimia yang dikategorikan sulit oleh siswa. Siswa pada umumnya kesulitan dalam memahami konsep pengendapan larutan, pengaruh ion-ion senama terhadap kelarutan. Konsep dalam Ksp termasuk konsep yang sulit dan kompleks dikarenakan mensyaratkan beberapa konsep seperti kelarutan, kesetimbangan kimia dan fisika, hukum Le Chatelier, kimia larutan dan persamaan kimia. Selain itu, siswa tidak bisa menghubungkan konsep sebelumnya dengan konsep kelarutan dan hasil kali kelarutan [4].

Hal ini didukung dengan ketuntasan nilai ulangan harian materi kelarutan dan hasil kali kelarutan kelas XI semester genap tahun pelajaran $2014 / 2015$ yang dapat dilihat pada Tabel 1.

Berdasarkan Tabel 1 dapat dilihat bahwa persentase ketuntasan siswa beberapa kelas pada materi kelarutan dan hasil kelarutan masih dibawah target ketuntasan yang ditetapkan yaitu $75 \%$ [5].

Tabel 1. Data Ketuntasan Ulangan Harian Kelarutan dan Hasil Kali Kelarutan Tahun Pelajaran 2014/2015.

\begin{tabular}{ccc}
\hline Kelas & KKM & Ketuntasan (\%) \\
\hline XI MIPA 1 & 70 & 45,95 \\
XI MIPA 2 & 70 & 59,37 \\
XI MIPA 3 & 70 & 34,28 \\
\hline
\end{tabular}

Materi kesetimbangan kimia merupakan materi yang memiliki aturan penting dalam pengembangan pemahaman pada materi kimia salah satunya kelarutan dan hasil kali kelarutan [6]. Pemahaman siswa terhadap konsep kesetimbangan kimia akan berpengaruh terhadap pemahaman siswa pada materi kelarutan dan hasil kali kelarutan [7]. Hal ini diperkuat dengan nilai ulangan kesetimbangan kimia kelas XI semester gasal tahun pelajaran 2015/2016 yang juga masih rendah.

Data ketuntasan ulangan harian materi pokok kesetimbangan kimia yang dapat dilihat pada Tabel 2.

Tabel 2. Data Ketuntasan Ulangan Harian Kesetimbangan Kimia KelasXI MIA SMA Negeri 2 Sukoharjo Tahun Pelajaran 2015/2016.

\begin{tabular}{cc}
\hline Kelas & Ketuntasan (\%) \\
\hline XI MIA 1 & 27,50 \\
XI MIA 2 & 15,38 \\
XI MIA 3 & 26,31 \\
\hline
\end{tabular}

Berdasarkan Tabel 2 dapat dilihat bahwa persentase ketuntasan siswa pada ulangan harian kesetimbangan kimia masih rendah yaitu dibawah $30 \%$, selain itu, kelas XI MIA 2 diketahui memiliki ketuntasan paling rendah dari ketiga kelas yang ada yaitu sebesar $15,38 \%$. Berdasarkan hasil UAS kimia kelas XI MIA semester gasal tahun pelajaran 2015/2016 diketahui bahwa nilai rata - rata kelas XI MIA 2 tergolong paling rendah yaitu 58. Hal ini mengindikasikan adanya suatu 
permasalahan dalam proses belajar mengajar kimia siswa kelas XI MIA 2 dan memerlukan perbaikan prestasi belajar.

Observasi lebih lanjut dilakukan dikelas XI MIA 2 tanggal 21 Januari 2016. Berdasarkan hasil observasi peneliti di kelas diketahui bahwadalam pembelajaran kimia aktivitas siswa terbatas pada mendengarkan materi yang disampaikan guru. Siswa kurang diajak untuk berdiskusi dalam menemukan konsep sendiri dari pengetahuan yang dimiliki sebelumnya sehingga siswa kurang diberikan kebebasan untuk menyampaikan ide-ide atau gagasan yang dimiliki. Siswa kurang berani bertanya jika terdapat langkah penyelesaian soal yang belum dipahami sehingga siswa mengalami kesulitan dalam menganalisis dan menyelesaikan soal - soal. Selain itu, siswa kurang mau menanggapi penjelasan guru, kurang antusias terhadap pembelajaran kimia, sehingga pembelajaran menjadi kurang bermakna, mudah dilupakan dan pada akhirnya prestasi belajar siswa menjadi rendah.

Berdasarkan angket yang telah diberikan kepada siswa kelas XI MIA 2, menunjukkan bahwa persentase aktivitas belajar siswa kelas XI MIA 2 masih tergolong rendah yaitu siswa dengan kategori aktivitas tinggi sebesar $30,76 \%$, sehingga dapat diketahui bahwa penyebab aktivitas belajar siswa rendah adalah karena siswa enggan bertanya kepada guru.

Berdasarkan permasalahanpermasalahan yang ada maka perlu dilakukan tindakan untuk memperbaiki kualitas pembelajaran melalui model pembelajaran yang aktif. Tindakan untuk memperbaiki kualitas proses pembelajaran dapat dilakukan melalui sebuah penelitian tindakan kelas (PTK) atau Classroom Action Research (CAR) [8].

Salah satu upaya yang dapat dilakukan adalah dengan menerapkan pembelajaran kooperatif tipe Team Assisted Individualization (TAI). Model ini mengkombinasikan keunggulan pembelajaran kooperatif dan pembelajaran individual. Siswa dibagi menjadi beberapa kelompok secara heterogen dimana pada setiap kelompok ada salah satu siswa yang memiliki kemampuan lebih dari yang lain sebagai asisten yang bertugas membimbing anggota kelompoknya yang masih kesulitan dalam memahami suatu materi.

Penelitian sebelumnya

menyatakan bahwa TAl dapat meningkatkan rasa ingin tahu dan prestasi belajar siswa pada matei kelarutan dan hasil kali kelarutan [9], selain itu diketahui bahwa TAI dapat meningkatkan prestasi belajar siswa di bidang sains dibandingkan metode konvensional [10].

Media pembelajaran menjadi hal yang penting bagi siswa dan guru dalam pembelajaran di kelas [11]. Salah satu media yang dapat digunakan untuk menunjang proses pembelajaran materi kelarutan dan hasil kali kelarutan adalah catatan terbimbing (guided note).

Catatan terbimbing (guided note) merupakan suatu lembaran berupa handout dimana terdapat poin-poin yang penting seperti istilah atau definisi, dan beberapa kata kunci yang dikosongi [12]. Pengisian catatan terbimbing (guided note) melibatkan keaktifan siswa dalam menulis, menganalisis dan menangkap isi dari materi pembelajaran, dapat memfokuskan perhatian siswa terhadap proses pembelajaran yang berlangsung dan membuat catatan siswa menjadi lebih teratur. Selain itu, media tersebut berfungsi sebagai sumber belajar pada proses student creative dan team study pada model pembelajaran Team Assisted Individualization (TAI).

Berdasarkan

penelitian sebelumnya, catatan terbimbing (guided note) dapat membuat catatan siswa menjadi teratur dan menimbulkan rasa ingin tahu siswa dalam praktikum kimia di laboratorium [13], dapat meningkatkan prestasi belajar siswa pada materi kimia [14], dapat meningkatkan aktivitas siswa dalam bertanya, dan prestasi belajar siswa dalam pelajaran matematika [15].

Berdasarkan uraian diatas maka peneliti bermaksud untuk melakukan penelitian tindakan kelas untuk meningkatkan aktivitas dan prestasi belajar siswa menggunakan model pembelajaran Team Assisted 
Individualization (TAI) dilengkapi catatan terbimbing (guided note) pada materi pokok kelarutan dan hasil kali kelarutan kelas XI MIA 2 SMA Negeri 2 Sukoharjo tahun pelajaran 2015/2016.

\section{METODE PENELITIAN}

Penelitian ini merupakan Penelitian Tindakan Kelas (PTK) yang dilaksanakan dalam dua siklus. Prosedur yang digunakan dalam Penelitian Tindakan Kelas ini mengikuti model yang dikembangkan Kemmis dan Mc Taggart yakni berupa siklus spiral yang terdiri dari empat tahap yaitu perencanaan (planning), pelaksanaan (action), observasi (observing), dan refleksi (reflecting). Subjek penelitian ini adalah siswa kelas XI MIA 2 SMA Negeri 2 Sukoharjo tahun pelajaran 2015/2016. Objek penelitian ini adalah aktivitas dan prestasi belajar.

Teknik pengumpulan data yang digunakan yaitu tes dan non tes. Tes disusun dan dilakukan untuk mendapatkan data prestasi belajar siswa sebagai aspek pengetahuan pada materi kelarutan dan hasil kali kelarutan. Non tes berupa data hasil observasi, angket aktivitas dan sikap, wawancara dan kajian dokumen. Validitas data menggunakan teknik triangulasi metode [16].

Teknik analisis data menggunakan analisis deskriptif kualitatif. Analisis data dalam penelitian ini mengacu pada model analisis Miles dan Huberman yang dilakukan dalam tiga tahap yaitu reduksi data, penyajian data, dan penarikan kesimpulan [17].

\section{HASIL DAN PEMBAHASAN}

\section{Siklus I}

\section{a. Perencanaan Tindakan}

Perencanaan tindakan meliputi penyusunan instrumen pembelajaran dan instrumen penilaian. Instrumen pembelajaran meliputi silabus, Rencana Pelaksanaan Pembelajaran (RPP) dan catatan terbimbing (guided note). Instrumen penilaian meliputi lembar observasi aktivitas dan sikap siswa pada setiap pertemuan, angket aktivitas dan sikap pada akhir siklus, soal tes pengetahuan pada akhir siklus, dan lembar observasi keterampilan untuk pertemuan ketiga saat praktikum.

Tindakan yang akan dilakukan direncanakan berdasarkan silabus kurikulum 2013 yang telah disusun oleh Permendikbud nomor 81A tahun 2013. Penelitian tindakan kelas pada siklus I dilaksanakan lima kali pertemuan dengan alokasi waktu empat kali pertemuan (8 x 45 menit) untuk menyampaikan materi dan satu pertemuan ( $2 \times 45$ menit) untuk evaluasi. Masing - masing pertemuan menggunakan model pembelajaran Team Assisted Individualization (TAI) dilengkapi catatan terbimbing (guided note) yang dirancang berdasarkan sintaks pembelajaran TAl. Pembagian kelompok secara heterogen terbagi menjadi 8 kelompok dengan 1 asisten.

\section{b. Pelaksanaan Tindakan}

Pada kegiatan awal pembelajaran guru memberikan apersepsi yang berkaitan dengan materi yang dikaitkan dengan kehidupan sehari-hari. Guru menggunakan model pembelajaran Team Assisted individualization (TAI) dilengkapi catatan terbimbing (guided note) dalam menjelaskan materi kelarutan dan hasil kali kelarutan. Kemudian siswa mempelajari sendiri materi dan mencoba mengerjakan soal yang ada di catatan terbimbing (guided note) secara individu (Student Creative). Guru kemudian meminta siswa berdiskusi dalam kelompoknya masing masing (Team Study) dibantu asisten (tutor). Setelah proses diskusi selesai, masing-masing kelompok mempresentasikan hasil diskusinya (Whole Class Unit). Guru menyamakan persepsi dan memberikan penguatan terhadap materi yang sedang dipelajari. Pada kegiatan akhir pembelajaran, guru memberikan soal posttest secara individu (Fact Test). Pada pertemuan ketiga, dilakukan kegiatan praktikum di laboratorium. Pertemuan kelima dilaksanakan evaluasi siklus I yang meliputi tes aspek pengetahuan. Waktu yang tersisa digunakan untuk pengisian angket aktivitas dan pemberian reward 
pembelajaran siklus I (Team Scores and team Recognition).

\section{c. Observasi Tindakan}

Observasi terhadap siswa dilakukan selama pembelajaran berlangsung. Pada awal pembelajaran, siswa masih belum terbiasa dengan model pembelajaran TAI dilengkapi catatan terbimbing, hal ini dapat dilihat dari hasil diskusi mereka dimana ada beberapa catatan terbimbing yang belum selesai dilengkapi. Namun pada pertemuan berikutnya siswa sudah cukup terlibat aktif dalam pembelajaran.

Hasil persentase ketercapaian aktivitas belajar siswa pada siklus I disajikan dalam Gambar 1.

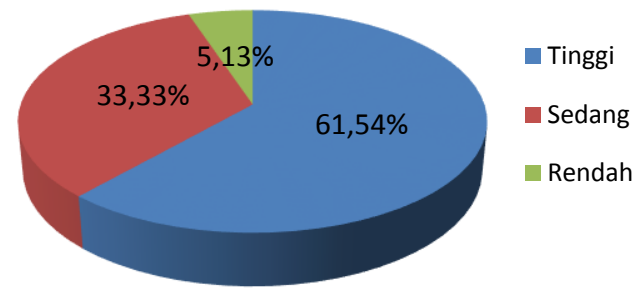

Gambar 1. Ketercapaian Aktivitas Belajar Siklus I

Gambar 1 menunjukkan bahwa ketercapaian aktivitas siswa sebesar $61,53 \%$, aktivitas siswa dengan kategori tinggi lebih banyak dibanding aktivitas kategori sedang dan rendah. Hal ini dikarenakan dalam siklus I, siswa terlibat aktif dalam kegiatan pembelajaran. Aktivitas siswa terlihat saat berdiskusi. Adanya catatan terbimbing (guided note), dapat meningkatkan visual dan writing activities dalam mencermati dan mengisi catatan terbimbing (guided note). Oral activities terllihat pada saat berdiskusi, siswa aktif bertanya pada asisten dan guru ketika melengkapi catatan terbimbing (guided note) dan mengerjakan soal diskusi. Adanya presentasi kelompok dapat meningkatkan emotional dan mental activities. Namun, ketercapaian aktivitas belajar belum mencapai target pencapaian, hal ini dikarenakan masih terdapat 3 aspek aktivitas siswa yang belum mencapai target yaitu aspek oral, mental dan emotional activities sehingga perlu diukur lagi pada siklus II.

Hasil penilaian aspek pengetahuan pada siklus I disajikan dalam Gambar 2.

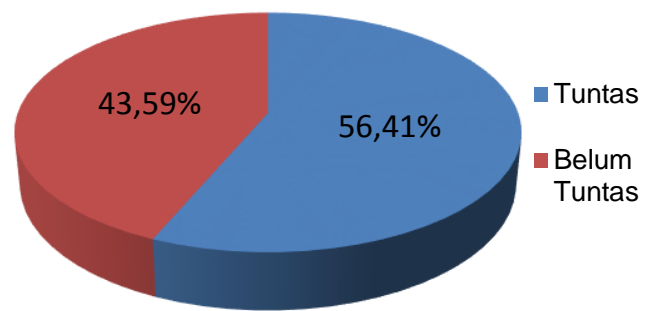

Gambar 2. Ketuntasan Aspek Pengetahuan Siklus I

Gambar 2 menunjukkan ketercapaian pengetahuan sebesar $56,41 \%$, ketuntasan siswa belum memenuhi target yang ditentukan yaitu $70 \%$ siswa tuntas, sehingga perlu dilanjutkan ke siklus II. Hasil analisis pengetahuan menunjukkan dari 20 indikator soal, masih terdapat 10 indikator soal yang belum tuntas, salah satunya yaitu indikator menentukan zat yang memiliki kelarutan paling besar dalam air jika diketahui Kspnya.Siswa masih kesulitan untuk memahami materi, masih kurang teliti untuk membaca soal, yang ditanyakan adalah kelarutan, namun kebanyakan siswa menjawab berdasarkan data Ksp yang paling besar dan tidak dicari kelarutannya dahulu. Selain itu, siswa kurang teliti dalam menghitung angka dengan pangkat negatif. Hal ini dikarenakan ada beberapa siswa yang kurang berpartisipasi aktif dalam diskusi kelompok (team study) dan ada yang menggantungkan penyelesaian soalnya pada asisten.

Hasil akhir penilaian sikap siklus I disajikan dalam Gambar 3. Gambar 3 menunjukkan ketercapaian aspek sikap sudah mencapai target pencapaian dengan capaian 94,87\%. Hal ini menunjukkan bahwa sikap siswa dalam kelas tersebut baik. Sikap siswa dapat terlihat dari kerjasama antar siswa ketika berdiskusi untuk menyelesaikan soal, hal ini dapat meningkatkan tanggungjawab karena siswa harus saling membantu dalam menyelesaikan tugasnya dan disiplin didalam kelas. 


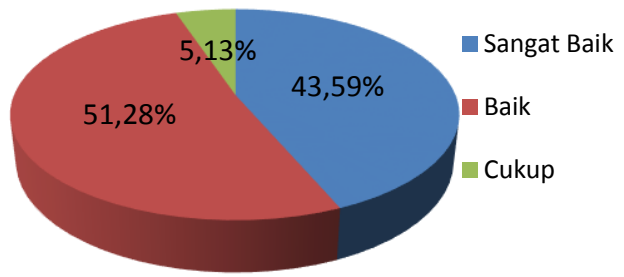

Gambar 3. Keterapaian Aspek Sikap Siklus I

Hasil penilaian aspek keterampilan disajikan dalam Gambar 4.

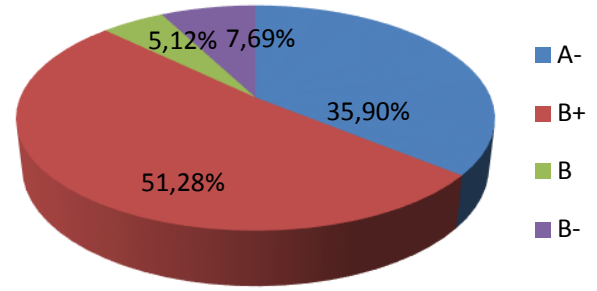

Gambar 4. Hasil Akhir Penilaian Aspek Keterampilan

Gambar 4 menunjukkan semua siswa memiliki nilai yang termasuk dalam kategori tuntas. Hal ini dikarenakan dalam kegiatan praktikum siswa terlibat aktif, saling berkerjsama dan dalam membuat laporan praktikum hamper semua siswa sesuai dengan pedoman penulisan laporan. Persentase ketuntasan siswa pada aspek keterampilan telah mencapai 100\%, sehingga aspek keterampilan tidak dilanjutkan pada siklus II.

\section{d. Refleksi}

Berdasarkan hasil evaluasi pada siklus I terdapat aspek yang belum mencapai target ketuntasan yaitu aspek aktivitas belajar dan pengetahuan, sehingga perlu dilakukan perbaikan pembelajaran pada siklus II.

Pada tindakan siklus I, terdapat kelompok yang aktivitasnya tinggi, sedang dan ada yang rendah, beberapa siswa masih ada yang belum menunjukkan keaktifannya dikarenakan malu untuk menyampaikan pendapat dalam diskusi, enggan untuk menarik kesimpulan dari materi yang sudah dipelajari. Terdapat asisten kelompok yang dianggap kurang jelas dalam membimbing temannya. Pada aspek pengetahuan masih terdapat beberapa indikator soal yang belum mencapai target. Hal ini disebabkan pada indikator tersebut terdapat materi yang sulit dan membutuhkan pemahaman konsep yang matang, beberapa indikator soal ada yang merupakan materi hafalan namun siswa kurang teliti dan belum memahami betul konsep materinya. Oleh karena itu, peneliti dan guru kimia melakukan diskusi untuk memperbaiki proses pembelajaran dan membuat perencanaan pada siklus II.

\section{Siklus II}

\section{a. Perencanaan Tindakan}

Perencanaan tindakan pada siklus II disusun berdasarkan hasil refleksi siklus I. Rencana tindakan pada siklus II yaitu siklus II dilaksanakan dalam 2 kali pertemuan dengan alokasi waktu masing - masing pertemuan $2 \times 45$ menit. Pertemuan pertama yaitu pemberian materi yang belum mencapai target ketuntasan. Pertemuan kedua dilakukan evaluasi pembelajaran.

Jumlah kelompok pada siklus II lebih banyak dari kelompok siklus I, yaitu sebanyak 10 kelompok. Guru mengganti asisten kelompok yang dianggap kurang jelas dalam menjelaskan materi sesuai asisten yang diusulkan. asisten berdasarkan tes pengetahuan siklus I dan hasil pertimbangan peneliti dan guru. Peneliti membuat instrumen pembelajaran yang meliputi RPP, catatan terbimbing (guided note). Instrumen RPP dan catatan terbimbing (guided note) hanya berisi indikator soal yang belum tuntas pada siklus I. Catatan terbimbing (guided note) diperbaharui dari segi konten materi dan latihan soal. Guru menekankan kepada siswa untuk menggunakan catatan terbimbing (guided note) pada siklus I sebagai bantuan dalam pemecahan masalah di siklus II.

\section{b. Pelaksanaan Tindakan}

Pembelajaran pada pertemuan pertama diawali dengan mengkondisikan masing - masing kelompok dan pembagian catatan terbimbing (guided 
note) (Teams). Kemudian guru memberikan apersepsi dengan memberikan pertanyaan dan mengingat kembali materi yang telah diajarkan sebelumnya (Teaching Group). Guru memberikan tugas kepada siswa untuk mempelajari materi kelarutan dan hasil kali kelarutan secara individual dan mengisi bagian kosong pada catatan terbimbing (Student Creative). Siswa diberikan tugas untuk mendiskusikan pemecahan soal - soal yang ada pada catatan terbimbing dalam kelompoknya dibantu asisten (Team Study). Setelah itu, guru memberi kesempatan kepada kelompok untuk mempresentasikan hasil diskusi (Whole Class Unit). Guru membahas hasil diskusi secara bersama - sama dengan tujuan agar siswa lebih paham dan memberikan penguatan tentang materi yang dipelajari. Guru memberikan soal posttest (Fact Test) untuk dikerjakan secara individu.

Pertemuan kedua dilaksanakan evaluasi siklus II yang meliputi tes aspek pengetahuan. Waktu yang tersisa digunakan untuk pengisian angket aktivitas dan pemberian reward pembelajaran siklus II (Team Scores and team Recognition).

\section{c. Observasi Tindakan}

Hasil persentase ketercapaian aktivitas belajar siswa pada siklus I disajikan dalam Gambar 5.

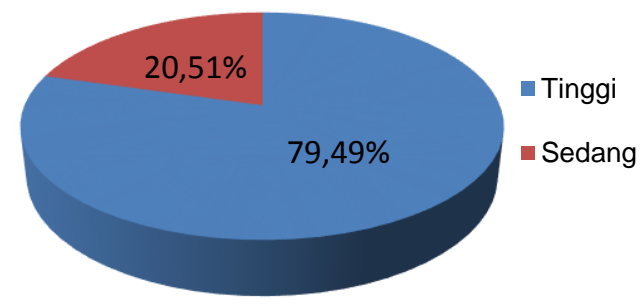

Gambar 5. Ketercapaian Aktivitas Belajar Siklus II

Gambar 5 menunjukkan persentase aktivitas belajar meningkat dari siklus I ke siklus II dan sudah memenuhi target $75 \%$ dengan capaian $79,49 \%$. Hal ini dikarenakan siswa sudah terbiasa dengan pembelajaran TAl yang dilengkapi catatan terbimbing (guided note). Siswa terlibat aktif dalam kegiatan pembelajaran. Oral acitivities meningkat saat berdiskusi (team study) dan mengisi catatan terbimbing. Jumlah siswa yang bertanya lebih banyak dari sebelumnya. Pada proses diskusi diketahui siswa yang aktivitasnya belum tuntas mulai aktif bertanya mengenai materi yang dianggap belum bisa. Emotional acitivies meningkat saat semua siswa terlihat antusias terhadap proses pembelajaran karena dapat bertanya kepada asisten, guru, maupun teman. Saat presentasi kelompok (whole class unit), terlihat siswa sudah tampil berani dalam menjelaskan jawabannya didepan kelas. Kelompok lain mengajukan pertanyaan kepada kelompokyang sedang maju. Mental activities meningkat saatsemua siswa mulai terbiasa menyimpulkan materi yang telah mereka pelajari. Visual dan writing activities terlihat ketika siswa mencermati dan mengisi catatan terbimbing (guided note).

Hasil persentase ketuntasan aspek pengetahuan disajikan dalam Gambar 6.

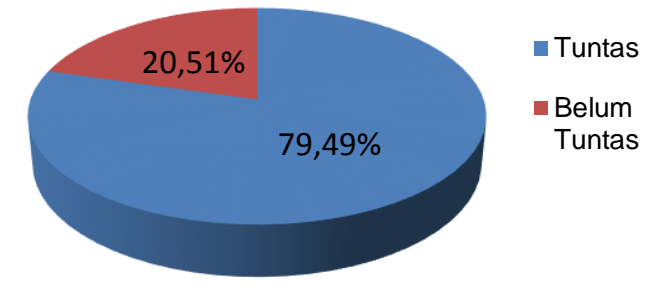

Gambar 6. Ketuntasan Aspek Pengetahuan Siklus II

Berdasarkan Gambar 6 ketuntasan aspek pengetahuan sudah memenuhi target $70 \%$ dengan capaian $79,49 \%$. Hal ini dikarenakan pada siklus II ini siswa terlihat lebih menguasai materi karena mereka sudah mendapatkan materi tersebut pada siklus I. Siswa terlibat aktif dalam proses pembelajaran sehingga mampu memecahkan soal - soal, selain itu siswa dan asisten saling membantu temannya yang belum tuntas. Berdasarkan pengamatan, siswa sudah memahami materi Kelarutan dan Hasil Kal Kelarutan, sehingga terjadi peningkatan persentase ketuntasan pada masing - masing indicator soal yang diuji pada siklus II. Hasil analisis pengetahuan menunjukkan dari 10 indikator soal, hanya terdapat 1 indikator soal yang belum tuntas, yaitu 
menentukan zat yang memiliki kelarutan paling besar dalam air jika diketahui Kspnya, hal ini mungkin dikarenakan siswa masih keliru dengan soal yang ditanyakan adalah kelarutan, namun kebanyakan siswa menjawab berdasarkan data Ksp yang paling besar dan tidak dicari kelarutannya dahulu.

\section{d. Refleksi}

Hasil aktivitas belajar siswa pada siklus II mengalami peningkatan dibanding dengan hasil pada siklus I. Penilaian aspek aktivitas belajar dan pengetahuan dinyatakan telah memenuhi target ketuntasan yang ditentukan, yaitu dengan ketercapaian sebesar $79,49 \%$. Hal ini dikarenakan dalam pembelajaran TAI dilengkapi catatan terbimbing ini pada siklus II inisiswa lebih aktif dan antusias dalam mengikuti diskusi maupun presentasi kelompok, siswa banyak menanggapi dan memberi pendapat kepada kelompok yang presentasi. Asisten sudah lebih cakap dalam membantu temannya yang mengalami kesulitan dalam mengerjakan soal.

\section{Perbandingan Hasil Tindakan Antar Siklus}

Perbandingan hasil tindakan siklus I dan II disajikan dalam Gambar 7.

Berdasarkan Gambar 7 diketahui aspek pengetahuan dan aktivitas belajar terjadi peningkatan dari siklus I dan II, dan semua aspek telah mencapai target yang ditetapkan sehingga pelaksanaan tindakan hanya sampai siklus II.

Peningkatan aktivitas dan prestasi belajar dikarenakan digunakannya model pembelajaran TAl yang dilengkapi catatan terbimbing (guided note). Model pembelajaran tersebut bersifat konstruktivisme dimana siswa mengkonstruksi pengetahuannya dalam materi kelarutan dan hasil kali kelarutan melalui diskusi dan pengisian catatan terbimbing yang menimbulkan aktivitas belajar siswa dalam bertanya, mengungkapkan pendapat, memecahkan soal dengan dibantu asisten, berani presentasi didepan kelas.

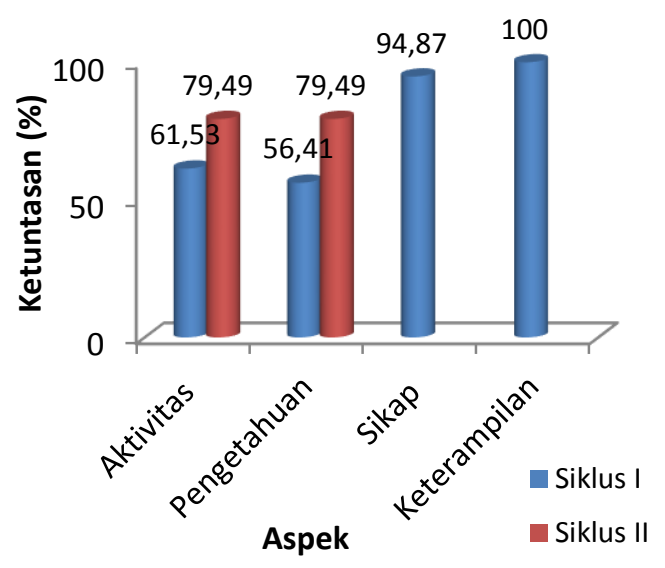

Gambar 7. Histogram Perbandingan Hasil Tindakan Siklus I dan Siklus II

Peningkatan aktivitas siswa mendorong peningkatan prestasi belajar siswa, sehingga dapat disimpulkan bahwa terjadi hubungan yang linier antara aktivitas dengan prestasi belajar. Pembelajaran kooperatif dapat meningkatkan aktivitas dan prestasi akademis siswa berbagai bidang studi [18].

\section{KESIMPULAN}

Berdasarkan penelitian yang telah dilakukan, dapat disimpulkan bahwa penerapan model pembelajaran Team Assisted Individualization (TAI) dilengkapi catatan terbimbing (guided note) dapat meningkatkan aktivitas dan prestasi belajar siswa pada materi pokok kelarutan dan hasil kali kelarutan kelas XI MIA 2 SMA Negeri 2 Sukoharjo tahun pelajaran 2015/2016.

\section{UCAPAN TERIMAKASIH}

Ucapan terimakasih penulis sampaikan kepada Dra. Dwi Ari Listiyani, M.Pd, selaku kepala SMA Negeri 2 Sukoharjo atas izin yang diberikan kepada penulis untuk melaksanakan penelitian serta Sri Martini Rochmiatun, S.Pd selaku guru mata pelajaran Kimia SMA Negeri 2 Sukoharjo, yang telah memberikan bimbingan dan membantu dalam penelitian ini. 


\section{DAFTAR RUJUKAN}

[1] Chang, R. (2005). Kimia Dasar Konsep - Konsep Inti. Edisi Ketiga (Jilid 2). Terj.M Abdulkadir Martoprawiro. Jakarta: Erlangga

[2] Susiwi. (2007). Pendekatan Pembelajaran dalam Pembelajaran Kimia. Bandung: Univeritas Pendidikan Indonesia.

[3] Mulyasa. (2014). Pengembangan dan Implementasi Kurikulum 2013. Bandung: Remaja Rosda Karya.

[4] Raviolo. (2001). Assesing Student's Conceptual Understanding of Solubility Equilibrium. Journal of Chemical Education, 78(5), 629-631.

[5] Depdiknas. (2008). Penetapan Kriteria Ketuntasan Minimal (KKM). Direktorat Jenderal Manajemen Pendidikan Dasar dan Menengah. Jakarta: Depdiknas

[6] Voska, K., \& Heikkinen, H. (2000). Identification and Analysis of Students'Conceptions Used to Solve Chemical Equilibrium Problems. Journal of Research in Science Teaching, 37(2), 160-176.

[7] Maharani. (2013). Menggali Pemahaman Siswa SMA pada Konsep Kelarutan dan Hasil Kali Kelarutan dengan Menggunakan Tes Diagnostik Two-Tier. Universitas Negeri Malang

[8] Aqib, Z. (2009). Penelitian Tindakan Kelas. Bandung: Yrama Widya.

[9] Shillahaque, G.P. (2015). Penerapan Model Pembelajaran Team Assisted Individualization (TAI) dengan Media Key Relation Chart untuk Mrningkatkan Rasa Ingin Tahu dan Prestasi Belajar Siswa pada Materi Pokok Kelarutan dan Hasil Kali Kelarutan Siswa Kelas XI MIA 1 SMA Negeri 5 Surakarta Tahun Pelajaran 2014/2015. Jurnal Pendidikan Kimia Universitas Sebelas Maret, 4(4), 80-86.
[10] Nneji, L. (2011). Impact of Framing and Team Assisted Individualization Instructional Strategies Student Achievement in Basic Science in The North Central Zone of Nigeria. Nigerian Educational Research Journal. 23(4), 1-8.

[11] Daryanto. (2013). Media Pembelajaran. Jakarta: Gava Media.

[12] Heward, W. (1994). Guided NotesImproving The Effectiveness of Your Lectures. The Ohio State University Partnership Grant.

[13] Amesbury, Christopher. (2006). Student Centered Learning in the Chemistry Classroom. Education and Human Development Master's Thesis Paper 288.

[14] Trujillo. (2014). Using Guided Notes to Improve Academic performance In a Chemistry Inclusion Classroom. Digital Commons. Florida International University

[15] Strange, C. (2013). Effect of Guided Notes on 6th Grade Math Students' Academic Achievement and Self-Perceptions of Learning. Education Senior Actions Research Projects. Paper 32.

[16] Moleong, L. (2009). Metodologi Penelitian Kualitatif. Bandung: PT. Remaja Rosdakarya.

[17] Sugiyono. (2013). Metode Penelitian Pendidikan dan R\&D. Bandung: Alfabeta

[18] Kagan, S. (1999). Cooperative Learning: Seventeen Cons plus Ten Tips for Succes. Diperoleh pada9 Juni 2017, dari https://www. kaganonline.com/free_articles/dr_ spencer_kagan/259/CooperativeLearning-Seventeen-Pros-andSeventeen-Cons-Plus-Ten-Tipsfor-Success. 